\title{
THE RED CROSS IN NEW GUINEA
}

The Australian Red Cross Reviere Action (1967, No. 14) gives an account of the progressive penetration which is being achieved by our movement in this territory where humanitarian initiative has only recently gained momentum. We believe our readers will be interested in the passages we have reproduced or summarized below.

Papua and New Guinea has been described as the land that the Twentieth Century nearly forgot. If this statement, which appears in many travel folders, has any relevance it certainly doesn't apply in regard to Red Cross and the many services and activities carried out by this most distant of all Divisions of the Australian Red Cross Society.

In the ensuing commentary an assessment will be made of the Society's work in the Territory to-day, and evidence will be given of how rapidly this Division has developed since it was formally constituted as the Papua and New Guinea Division of the Australian Red Cross Society on the 21st June, 1949

Blood is vital. - Perhaps the Division's most significant development has been the expansion of the Blood Transfusion Service. Significant, because it is universally accepted that the recruitment of Blood Donors in an under-developed or emerging society is one of the most obdurate problems encountered.

However, of all blood donations received in the Territory, 87 per cent comes from Papuans and New Guineans. The Director of the Blood Transfusion Service reported recently that there is no problem in donor recruitment as the fear of sorcery has been largely dispelled among the indigenous population when they are visited by the mobile teams

The "loss of face" motive operates strongly among Melanesians so that if one or two in a village come forward as donors the rest tend to follow almost automatically. The extent to which the 


\section{IN THE RED CROSS WORLD}

Blood Transfusion Service has developed in the Territory in recent years may be gauged by the fact that in 1959 the number of donations received was 1,620 , whereas this figure had risen to 11,425 last year.

Of equal importance to the ready acceptance of the giving of blood by the indigenous population is the increasing number of Papuans and New Guineans who have already qualified, or are at present being trained, to replace the European sisters. In addition, indigenous technicians carry out important laboratory work at the Blood Transfusion Centre in Port Moresby.

It is the aim of our Society that eventually the Red Cross Blood Transfusion Service will be staffed and run predominantly by trained Papuans and New Guineans under the direction of an indigenous doctor.

Helping the handicapped. - The Blood Transfusion Service has been maintained in the Territory since 1956. A service established in much more recent times is the care of mentally and physically handicapped children. In 1964, following a survey made in and around Port Moresby, it was established that there were 204 handicapped children in need of special treatment. Following this survey a local doctor and two voluntary physiotherapists began treating those children who could be brought to the Centre. This treatment was carried out in a room which had been specially equipped at Divisional Headquarters.

A bus to transport other children from outlying villages, wheel chairs and other equipment were donated by members of the Australian Junior Red Cross. As this service grew rapidly the need of a full-time physiotherapist to care for the 30 children attending the centre became apparent.

To-day, thanks to the assistance of the Australian Volunteers Abroad Association, treatment at this Centre is under the supervision of a physiotherapist from Adelaide, who is assisted by two indigenous helpers.

Juniors play their part. - In Papua and New Guinea too this Junior section of our Society is most active and the children have a close link with their Australian "brothers" and "sisters". 
One of the projects which is doing much towards creating friendship and better understanding between the children of both countries is the "adoption" system.

Australian J.R.C. Circles and Clubs are now paired with specific native schools, and these adoptions lead to an exchange of albums, letters and gifts.

As in Australia the Juniors in the Territory work to raise money for specific projects. The Juniors at one primary school in Rabaul have in fact raised over $\$ 1,600$ for Red Cross in the past five years And, although removed in distance by some thousands of miles, the children at this school were greatly concerned to learn of the suffering of the children in the Tasmanian Bushfire Disaster. They recently conducted a special " working bee " which raised $\$ 65$, and this was sent to assist the children who were the victims of the Hobart fires.

The membership of Junior Red Cross in the Territory continues to increase dramatically. In the past two years it has risen from 2,200 to 4,500 members. Of these $4,500-3,750$ are Papuans and New Guineans.

So that the interest of these Juniors will not be lost when they leave school it is planned that in the near future Younger Sets will be formed.

Indigenous Field Officers. - Helping to form these Younger Sets, under the direction of the Division's General Secretary and also the Director of Junior Red Cross, will be two indigenous Field Officers employed by Red Cross in the Territory.

They came to Melbourne to do a training course at National Headquarters and they have applied themselves diligently to the task of forming new indigenous Branches. Already three such Branches, with their own indigenous office bearers, have been formed at Hanuabada, Popondetta and Goroka in the Eastern Highlands

At Goroka, Mark conducts a First Aid Class for students from the Teachers' College. His weekly "Picture-night" is a great attraction for the indigenous population in a land that has not experienced the mixed blessing of television. In addition, Mark conducts a weekly programme on the local radio station, and in 


\section{IN THE RED CROSS WORLD}

the time allotted by courtesy of the Australian Broadcasting Commission he keeps both the European and indigenous population informed of local and national Red Cross activities.

Unlike Mark, whose activities are confined to the Highlands, Max serves the Division in the South. He is a member of the Junior Chamber of Commerce and is extremely well received wherever he travels. In addition to forming Branches at Hanuabada and Popondetta, Max recently established three new Junior Red Cross Circles in and around the sub-district of Rigo, some 50 miles east of Port Moresby. In Port Moresby itself he has also been successful in conducting a series of First Aid Classes, each of which extended over a period of ten weeks. Further classes in First Aid as well as Home Nursing are planned to commence in the near future.

Red Cross is fortunate that it has been able to retain the services of these, our first two local Field Officers, and it is the long range plan of the Division ultimately to have a trained indigenous Field Officer for each district in the Territory.

Gemo Island. - Approximately 7 per 1,000 of the population throughout the Territory are afflicted with leprosy, whereas the incidence of tuberculosis is mainly isolated to the coastal districts. At Gemo Island, just three miles across the Port Moresby harbour, the Administration maintains a hospital staffed by the London Missionary Society. This hospital cares for 80 Hansenide patients and 180 with Tuberculosis. The staff, most of whom are Papuans having been trained on the island, are most grateful for the practical interest that Red Cross takes in the patients. In fact, many of the comforts enjoyed by them are provided by our Society's voluntary workers.

One of our Papuan Junior Red Cross Circles has " adopted" the island and all of its efforts are devoted to helping the sick children at this Colony. In several of the Australian Divisions Junior Circles have also "adopted "Gemo and they send regular consignments of toys, bandages, wool and school requisites.

Other services. - So far this account of Red Cross work in Papua and New Guinea has dealt with some of the interesting and more dramatic Red Cross services carried out in the Territory. 
It would be an omission, however, to overlook those other well established services which are rendered to the community right throughout the year.

One of the Division's outstanding achievements is the maintenance of the Lae Hostel for mothers and babies receiving medical treatment and for relatives visiting dangerously ill patients. This hostel provides excellent accommodation and maintains at exceptionally low cost an essential service for patients and families from outlying areas.

Kiosks at the Taurama General Hospital (Port Moresby), Madang and Lae Hospitals, also render a valuable service to patients and visitors alike. Their worth is recognised by the Territory's Department of Public Health, without whose co-operation these buildings would not exist.

Thanks to the untiring assistance of our voluntary helpers each kiosk is trading at a profit and the surplus, although not great, helps to finance other vital Red Cross services.

Plans for new hostels and kiosks are at present being considered for Mount Hagen and Kavieng. In addition, at Goroka, land has already been purchased on which a modern and fully equipped Red Cross Centre will be erected later this year.

Amongst the other important community services rendered by the Division one would have to include the Hospital Visiting and Library Service, the escort service for families travelling to Australia for medical treatment, and the Medical Loan Service and provision of medical supplies and amenities to the sick. 